\title{
The principle of autonomy in Brazil: one needs to discuss it ...
}

\section{O princípio da autonomia no Brasil: discutir é preciso...}

\author{
Odile Nogueira Ugarte'; Marcus André Acioly².
}

A B S T R A C T

\begin{abstract}
The principle of patient autonomy is a cornerstone of bioethics. According to this concept, patients should be given the power to make decisions related to their treatment. It is an important component of modern medical ethics, which has received much interest in current literature. However, the rate of participation of patients and their willingness to participate are variable according to the cultural, social and family environments in which they are inserted. The aim of this paper is to promote a brief descriptive review on autonomy, the preferences of patients and the use of informed consent as an instrument for the exercise of autonomy in literature, and to stress the lack of debate, as well as the pressing need for discussion of these current issues nationwide.
\end{abstract}

Key words: Personal autonomy. Informed consent. Ethics.

\section{INTRODUCTION}

$M$ orality is the concept of what is or is not socially acceptable. Morality comes from the social conventions about what is considered right or wrong, from an implicit consensus among members of a particular community. The ethical theory, in turn, comes from the analysis of morality, the study and understanding of its nature, as well as its function'. Medical ethics deals with the study of morality applied to medical practice. The analysis of the moral issues related to professional behavior led to the creation of codes of professional ethics, including codes of medical ethics, aiming to guide and establish rules of conduct for the practice of medicine.

The proposed codes of professional ethical terms can vary between countries, but generally they rely on the principles of respect for autonomy, beneficence, nonmaleficence and justice. Of the four elements, the principle of autonomy is perhaps the most discussed in the ethics literature, especially the literature on the doctor-patient relationship and on obtaining informed consent ${ }^{2}$.

The term autonomy means the ability to selfgovern. For an individual to be autonomous, ie able to perform autonomous choices, it is necessary that this individual is able to act intentionally and has the freedom to do so. Minors, individuals who suffer from certain mental illnesses and those with altered level of consciousness are examples of agents that permanently or temporarily lack the capacity to act intentionally. The lack of capacity makes autonomous actions impossible ${ }^{1-3}$. Similarly, even one is considered capable when one's freedom to act is restricted, as in the case of prisoners, for example, autonomous action also cannot exist. Beyond the conditions capacity and freedom, nobody can exercise autonomous action if not informed about the objectives of the action and its consequences. Without understanding there is no autonomy ${ }^{1,2}$. Much has been discussed about the level of understanding of medical procedures that patients can achieve. Some claim that, being laymen, patients do not have sufficient understanding of the proposed procedures so as to know exactly what they are consenting when they allow them ${ }^{4,5}$. Defenders of patient autonomy believe they are able to understand the points considered important by their doctor. This understanding is only possible in a welcoming environment, in which the doctor strives to meet patients' concerns, and in which the debate is stimulated.

The physician should not, in any way, try to persuade one to accept a treatment with which one does not agree. Similarly, the professional should not take advantage of situations in which the patient is unable to decide, to convince him, as in the case of individuals under sedation ${ }^{2,3}$. The exercise of patient autonomy is possible only if the physician complies with a duty to inform with clarity and with the duty to assist in the decision making process. Questions should be encouraged when necessary ${ }^{1-3,6}$. Respect for autonomy is upheld in the Brazilian Code of Medical Ethics (Chapter V, Article 31), according to which it is prohibited to the doctor to "Disregard the right of the patient or his legal representative to freely decide on the performance of diagnostic or therapeutic practice, except

Discipline of Neurosurgery, Department of Surgery and Specialties, Hospital Antônio Pedro, Universidade Federal Fluminense - UFF.

1. Department of Neurosurgery, Hospital Federal do Andaraí - Rio de Janeiro, Brazil; 2. Discipline of Neurology, Postgraduate Department Universidade Federal do Estado do Rio de Janeiro - UNIRIO. 
in case of imminent danger of death". With this article, the code of medical ethics emphasizes the obligation to respect patient autonomy? ${ }^{7}$. The practice of respect for patient autonomy is opposed to the traditional paternalistic model of care. In paternalism all decisions concerning the treatment are taken by the doctor alone. The paternalistic model prevents the participation of the patient as an agent in his/her own treatment ${ }^{1,2}$. Between the two extremes represented by the total patient autonomy and the paternalistic model, there is the model of participative decision. The participative model can be regarded as ideal from the ethical point of view, in which the doctor informs, advises and guides the patient, through encouragement, in making free and informed decisions ${ }^{1,2}$. Thus, the adoption of the participatory model requires the involvement of both the physician and the patient, both being active agents in decision-making. Information sharing is a basic premise of participative relationship and making decisions together can only occur in an environment where there is sincerity and trust. Both patient and physician must agree with the final decision ${ }^{1-3,6}$. Studies show many benefits of adherence to this model: increased satisfaction, improved quality of life, increased confidence in the treatment and increased knowledge about the disease itself6.

Encouraging the participation of the patients must be done according to their own individual characteristics. Every patient has the right to decide based on his/her own system of beliefs and values, and has the right to have his/ her decisions respected. Expectations and desires of each patient are extremely peculiar and can vary widely according to their familial, cultural, social and religious characteristics ${ }^{8-}$ ${ }^{13}$. Other factors influencing the patient's desire to participate are his/her trust in the doctor, the existence or absence of therapeutic options and the nature of the care received, whether public or private ${ }^{6}$. Some individuals value the commercial aspect of the doctor-relationship patient and associate the right to participate to the fact that they are paying for the treatment. Likewise, patients in the Unified Health System (SUS) may feel obliged to agree unconditionally because they believe that by disagreeing, they could lose their right to medical care. Experiences of previous hospitalizations may also influence the relationship and some patients feel afraid to pester the doctor with questions or even acknowledge their right to participate ${ }^{6}$. The participation of patients, therefore, needs stimulation, through the establishment of trust and encouragement of exchange of information. The good doctor-patient relationship allows the identification of the needs of each patient and is critical to the success of any therapy. Expectations of each individual must be identified and respected, including in cases of refusal of treatment ${ }^{8-11}$. The ultimate goal of the professional should be the preservation of the interests and welfare of the patient ${ }^{1,2}$

The attitude of patients towards this ethical ideal of participation also varies between different countries. A US study conducted in 1995 with 200 individuals from four distinct ethnic groups found significant differences in behavior between groups. American descendants of Koreans and Mexicans showed less tendency to believe that the patient should know the diagnosis when the prognosis is negative, stating that the responsibility should be delegated to a family. The model focused on family responsibility was defended by the descendants of Koreans and Mexicans, in contrast to the patients of European and African origin, who preferred a model more focused to the patient himself. The variations in the pattern of preferences were also correlated with socioeconomic status. Patients of the same ethnic groups with higher levels of education and higher social classes had greater similarity to those of European and African origin, showing preference for model based on patient autonomy ${ }^{14}$

A study in China showed that the preferred model in the country is the protection of the patient through the omission of certain information. The patient should be protected from adverse information that might harm his/ her well-being and therefore their treatment. The consent for surgical procedures should be obtained from the family. The family decides what information can be passed to the patient and what should be omitted ${ }^{15}$.

In 2010, 360 Spanish patients underwent a questionnaire by Delgado et al. The data revealed that while the majority of the interviewees wished to be heard and informed by the doctor, the patients' autonomous participation was seen as an undesired increase in their accountability. More serious diseases are also associated with an even lower wish to participate ${ }^{16}$.

In Europe, a study published in 2005 interviewed individuals from Germany, Italy, Poland, Slovenia, Spain, Switzerland, Sweden and the UK. The desire to have an active role in decisions related to treatment was higher among German and Swiss populations. The Spanish population had the highest proportion of patients who desired a passive role in the relationship with the doctor ${ }^{17}$.

In Brazil there is still a lack of studies that identify the pattern of preferences of our population regarding the role of the patient in treatment. A study on the understanding of informed consent, in terms of its readability, found differences between the various education and socioeconomic levels. As discussed earlier, the informed consent (IC) is one of the tools that guarantee the full exercise of autonomy. The study then discusses the need to adapt the text to the characteristics of each patient in order to facilitate understanding, and discourages the use of standardized forms ${ }^{18}$.

For the patients to exert their independence, no therapeutic procedure can be performed without consent; in theory, it can be obtained in a verbal or written manner. Since every decision must be made consciously, the act of consent can be considered valid only if it is preceded by a clear explanation of the benefits and potential risks that each procedure offers. Thus, the duty to inform is an essential condition to validate the consent $t^{1,2,18-21}$. The 
definition of informed consent may be philosophically divided into five analytical components, namely: competence or ability of the patient, information, understanding, willingness and consent. In other words, the consent must be given by a capable individual, who has received and understood the required information and that voluntarily authorizes the procedure ${ }^{1,2,22}$. It is necessary that the patient is capable of understanding and deciding, that the decision is voluntary and that the information was provided in a clear and appropriate manner.

The consent itself does not occur at a specific moment in time, but is progressive process constructed through the physician-patient relationship. The signing of IC formalizes this relationship ${ }^{1,2,21}$. The presentation of an informed consent form to the patient should be seen as an opportunity for dialogue and encouraging questions, allowing the doctor to better understand the patient and the sociocultural environment in which he/she is inserted ${ }^{22}$. The institutional use of IC is increasingly common ${ }^{18,20}$.

The IC shall contain the identification of the patient and of his legal guardian, if applicable, the procedure name, the description of the procedure in clear, accessible language, the description of the most common risks and possible complications, explanations regarding the possibility of change in behavior due to unexpected events during its execution, a statement that the information have been understood, confirmation of the authorization, the place and date of the procedure. The signature of witnesses and the presentation of a model for revocation of the consent are also desirable ${ }^{20}$.

Although originally created within the ethical principles of respect for the patient, over time the IC acquired a legal value, defensive in character. The interpretation of the IC as a tool of legal defense can lead the doctor to exaggeration in information regarding risks and distortion of good doctor-patient relationship. The patient's right to information should not be regarded as mere protection against possible litigation ${ }^{20,22}$.

The benefits to the physician-patient relationship by adopting the participative model are undisputed. The opportunity to participate in decisions increases the rates of patients satisfaction with treatment and their confidence in the doctor. Within this context, the IC is a useful tool that can ensure the exercise of the right to autonomy when implemented well, and should not be seen only as a tool of legal defense. We observed a very early discussion, reflected by a significant lack of studies on the topic in the national literature, which, given the disparity with the international literature, shows the urgent need for debate in the society. The Brazilian model of health, based on the public system, suggests a paternalistic attitude on the part of physicians and patients. Studies of expectations and preferences of Brazilian patients are needed, so that models that correspond to our own cultural characteristics can be created. The adoption of health policies that comply with the basic principles of bioethics depends on this debate.

\title{
R E S U M O
}

\begin{abstract}
O princípio de autonomia do paciente é um dos pilares da bioética. Segundo este conceito, ao paciente deve ser dado o poder de tomar as decisões relacionadas ao seu tratamento. Trata-se de um componente importante da ética médica moderna, que tem recebido bastante interesse na literatura atual. No entanto, o índice de participação dos pacientes e a sua vontade de participar são variáveis de acordo com o meio cultural, social e familiar no qual se encontram inseridos. O objetivo do artigo é promover uma breve revisão descritiva referente à autonomia, às preferências dos pacientes e ao uso do consentimento informado como instrumento para o exercício da autonomia na literatura mundial e situar a carência do debate, bem como, a necessidade premente da discussão desses temas atuais em âmbito nacional.
\end{abstract}

Descritores: Autonomia Pessoal, Consentimento Livre e Esclarecido, Ética.

\section{REFERENCES}

1. Beauchamp TL, Childress JF. Principles of biomedical ethics. 4th ed. New York: Oxford; 1994.

2. Faden RR, Beauchamp TL. A history and theory of informed consent. New York: Oxford; 1986

3. Etchells E, Sharpe G, Dykeman MJ, Meslin EM, Singer PA. Bioethics for clinicians: 4. Voluntariness. CMAJ.1996;155(8):1083-6.

4. Ingelfinger FJ. Arrogance. N Engl J Med. 1980;303(26):1507-11.

5. Ingelfinger FJ. Informed (but uneducated) consent. N Engl J Med. 1972;287(9):465-6.

6. Fraenkel L, McGraw S. What are the essencial elements to enable patient participation in medical decision making? J Gen Intern Med. 2007;22(5):614-9.

7. Brasil. Conselho Federal de Medicina. Resolução CFM n 1246, de 08 de janeiro de 1988. Código de Ética Médica. Diário Oficial da União. Brasília, DF, 26 jan. 1988, Seção 1, p. 1574-7.
8. Weiner SJ. Contextualizing medical decisions to individualize care: lessons from the qualitative sciences. J Gen Intern Med. 2004;19(3):281-5.

9. Levinson W, Kao A, Kuby A, Thisted RA. Not all patients want to participate in decision making. J Gen Intern Med. 2005;20(6):5315.

10. Robinson A, Thomson R. Variability in patient preferences for participating in medical decision making: implication for the use of decision support tools. Qual Health Care. 2001;10 Suppl 1:i34-8.

11. Huijer $M$, van Leeuwen $E$. Personal values and cancer treatment refusal. J Med Ethics. 2000;26(5):358-62

12. Müller-Engelmann $M$, Krones $T$, Keller $H$, Donner-Banzhoff $N$. Decision making preferences in the medical encounter-a factorial survey design. BMC Health Serv Res. 2008;8:260.

13. Bruera E, Sweeney C, Calder K, Palmer L, Benisch-Tolley S. Patient preferences versus physician perceptions of treatment decisions in cancer care. J Clin Oncol. 2001;19(11):2883-5. 
14. Blackhall L, Murphy ST, Frank G, Michel V, Azen S. Ethnicity and Attitudes toward patient autonomy. JAMA. 1995;274(10):820-5.

15. Pang MC. Protective truthfulness: the Chinese way of safeguarding patients in informed treatment decisions. J Med Ethics. 1999:25(3):247-53.

16. Delgado A, López-Fernández LA, de Dios Luna J, Saletti Cuesta L, Gil Garrido N, Puga González A. Expectativas de los pacientes sobre la toma de decisiones ante diferentes problemas de salud. Gac Sanit. 2010;24(1):66-71.

17. Coulter A, Jenkinson C. European patients' views on the responsiveness of health systems and healthcare providers. Eur J Public Health. 2005;15(4):355-60.

18. Biondo-Simões MLP, Martynetz J, Ueda FMK, Olandoski M. Compreensão do termo de consentimento informado. Rev Col Bras Cir. 2007;34(3):183-8.

19. Etchells E, Sharpe G, Walsh P, Williams JR, Singer PA. Bioethics for clinicians: 1. Consent. CMAJ.1996;155(2):177-80.
20. Minossi JG. O consentimento informado. Qual o seu real valor na prática médica? Rev Col Bras Cir. 2011;83(3):198-201.

21. del Carmen MG, Joffe S. Informed consent for medical treatment and research: a review. Oncologist. 2005;10(8):636-41.

22. Schmitz D, Reinacher PC. Informed consent in neurosurgerytranslating ethical theory into action. J Med Ethics. 2006;32(9):4978.

Received on 15/12/2013

Accepted for publication 06/05/2014

Conflict of interest: none.

Source of funding: none.

\section{Mailing address:}

Odile Nogueira Ugarte

E-mail: odile.nu@gmail.com 